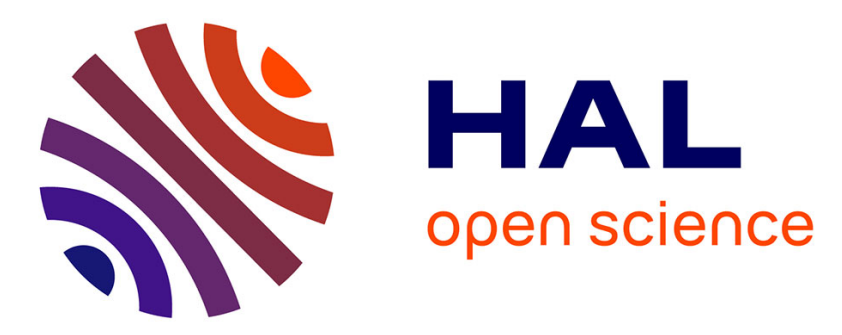

\title{
Influence of minor additions to Fe-Mn-Al alloys in an oxidizing environment - Role of a cerium oxide modified surface on silicon containing alloys
}

\author{
H. Buscail, P. Sotto, J. Larpin
}

\section{- To cite this version:}

H. Buscail, P. Sotto, J. Larpin. Influence of minor additions to Fe-Mn-Al alloys in an oxidizing environment - Role of a cerium oxide modified surface on silicon containing alloys. Journal de Physique IV Proceedings, 1993, 03 (C9), pp.C9-309-C9-315. 10.1051/jp4:1993930 • jpa-00252368

HAL Id: jpa-00252368

https://hal.science/jpa-00252368

Submitted on 1 Jan 1993

HAL is a multi-disciplinary open access archive for the deposit and dissemination of scientific research documents, whether they are published or not. The documents may come from teaching and research institutions in France or abroad, or from public or private research centers.
L'archive ouverte pluridisciplinaire HAL, est destinée au dépôt et à la diffusion de documents scientifiques de niveau recherche, publiés ou non, émanant des établissements d'enseignement et de recherche français ou étrangers, des laboratoires publics ou privés. 


\title{
Influence of minor additions to Fe-Mn-Al alloys in an oxidizing environment - Role of a cerium oxide modified surface on silicon containing alloys
}

\author{
H. Buscail, P. Sotto and J.P. Larpin
}

Laboratoire de Recherches sur la Réactivité des Solides, Faculté des Sciences Mirande, B.P. 138, 21004 Dijon Cedex, France

\begin{abstract}
Various silicon containing Fe-Mn-Al alloys were studied to estimate the influence of the silicon content on their oxidation behaviour. Silicon has a beneficial effect. Diffusion properties seem to be modified in the alumina scale grown at the scale substrate interface. Then, both scale growth and adherence are strongly affected. One possibility for modifying scale growth properties without changing the strength of the base alloy involves surface additions. The oxidation behaviour of a $\mathrm{CeO}_{2}$ surface modified $\mathrm{Fe}-\mathrm{Mn}-\mathrm{Al}-(\mathrm{Si})$ alloy was studied at $850^{\circ} \mathrm{C}$ in pure oxygen for exposure times up to $70 \mathrm{~h}$. A significant improvement in corrosion resistance of the silicon free alloy was observed after dipping in a cerium containing sol. This result is in accordance with the classical beneficial effect of "active elements". On the other hand, cerium deposition on a silicon containing Fe-Mn-Al alloy leads to an opposite result. The inhibition of the beneficial silicon effect by cerium additions will be discussed.
\end{abstract}

\section{Introduction.}

This paper describes a study concerning the isothermal oxidation of three austenitic steels: Fe-32Mn-6, 6Al, Fe-30Mn-6, 2Al-0.55Si and Fe-31 Mn-6, 8Al-0.8Si. They will be called Fe-Mn$\mathrm{Al} ; \mathrm{Fe}-\mathrm{Mn}-\mathrm{Al}-0.5 \mathrm{Si}$ and $\mathrm{Fe}-\mathrm{Mn}-\mathrm{Al}-0.8 \mathrm{Si}$, respectively in the following pages. From a practical point of view the advantage of the so-called "poor man's stainless steels" by Ham and Cairns [1] is the replacement of nickel and chromium by manganese and aluminium. Some authors have studied these alloys in sulfidizing environments and have demonstrated that Fe-Mn-Al alloys [2-4] are highly corroded in $\mathrm{H}_{2} \mathrm{~S} / \mathrm{H}_{2}$ mixtures or pure sulfur vapor. Preoxidation treatment is commonly used to prevent degradation of the substrate by formation of a protective oxide scale. The protectiveness of the oxide scale depends upon its chemical composition, porosity and adherence [4]. Silicon additions up to $1.5 \mathrm{wt} \%$ enhance oxidation resistance and strength, but decrease austenite stability $[5,6]$. The resulting austenitic Fe-Mn-Al-Si alloys show promising mechanical properties and oxidation resistance [3, 7-11]. Thus, silicon additions as an alloying element could be the first method for improving the oxidation resistance of such alloys.

On the other hand, some authors $[12,13]$ have demonstrated that reactive element additions such as cerium or yttrium on Fe-Ni-Cr alloys have a beneficial effect on the oxide scale mechanical properties and lowers the oxidation kinetics at high temperature. Active element surface deposition could then be another promising possibility for improving the corrosion resistance of Fe-Mn-Al alloys. Until now, no investigations have been performed on this topic. 
Our coatings have been applied on the three studied alloys using a sol-gel method. Kinetic results and oxide scale structure are discussed.

\section{Experimental.}

Weight gains were followed by thermogravimetry using a Setaram MTB 10-8 microthermobalance described elsewhere [14]. Oxide morphologies and partitioning of different elements were determined by scanning electron microscopy (S.E.M.) and energy dispersive Xray analysis (E.D.X.). Identification of the different phases was done using X-ray diffraction (X.R.D.). Rectangular plate samples of $3 \mathrm{~cm}^{2}$ were cut from the ingots and metallographically abraded to a $10 \mu \mathrm{m}$ finish, then washed in water and alcohol and dried before introduction into the reaction tube. Preparation of the samples by the Ce sol-gel technique was performed as follows: cerium hydroxide, $\mathrm{Ce}(\mathrm{OH})_{4}$, was prepared from ammonium cerium nitrate and ammonia. The samples were dipped for 1 minute in the solution, then dried in air. Directly after coating, the specimen was introduced into the reaction chamber. Coated and uncoated specimens were tested in pure oxygen $\left(p_{\mathrm{O}_{2}}=20000 \mathrm{~Pa}\right)$ at $850^{\circ} \mathrm{C}$.

\section{Results.}

\subsection{UNCOATED SPECIMENS.}

3.1.1 Oxidation kinetic. - Weight-gain results obtained on uncoated alloys tested at $850{ }^{\circ} \mathrm{C}$ are shown in figure 1 . The Fe-Mn-Al weight-gain curve shows a relatively high oxidation rate.

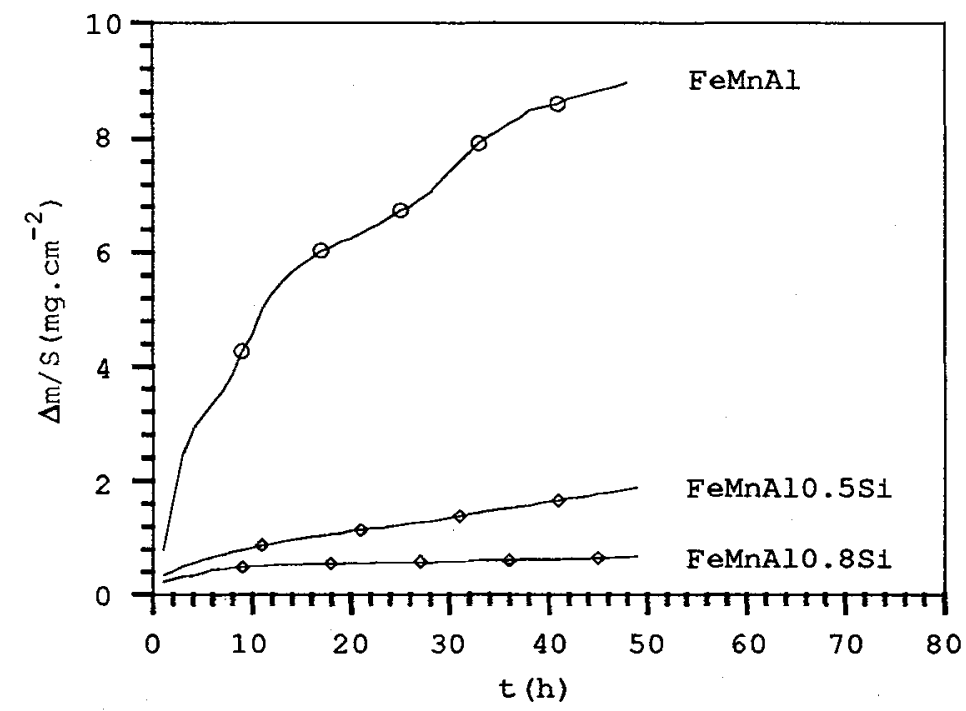

Fig. 1. - Oxidation kinetics of Fe-Mn-Al, Fe-Mn-Al-0.5Si, Fe-Mn-Al 0.8Si alloys; $p_{\mathrm{O}_{2}}=20000 \mathrm{~Pa}$, $T=850^{\circ} \mathrm{C}$. 
Three consecutive parabolic regimes were observed on the curve up to 50 hours oxidation, the total weight-gain being almost $9 \mathrm{mg} \mathrm{cm}^{-2}$. Concerning Fe-Mn-Al-0.5Si and Fe-Mn-Al$0.8 \mathrm{Si}$ alloys, the weight-gains measured after 50 hours were respectively, $2 \mathrm{mg} \mathrm{cm}^{-2}$ and $1 \mathrm{mg} \mathrm{cm} \mathrm{cm}^{-2}$. From the slopes of the plotted square root of weight-gain per unit area versus time, the following parabolic rate constants were calculated:

$k_{\mathrm{P}(\mathrm{Fe}-\mathrm{Mn}-\mathrm{Al}-0,8 \mathrm{Si})}=1.15 \times 10^{-12} \mathrm{~g}^{2} \mathrm{~cm}^{-4} \mathrm{~s}^{-1}$,

$k_{\mathrm{P}_{(\mathrm{Fe}-\mathrm{Mn}-\mathrm{Al}-0,5 \mathrm{Si})}}=1.50 \times 10^{-11} \mathrm{~g}^{2} \mathrm{~cm}^{-4} \mathrm{~s}^{-1}$.

3.1.2 Oxide scale morphology. - The oxide scale cross-section of the Fe-Mn-Al-0.8Si alloy oxidized at $850^{\circ} \mathrm{C}$ for 50 hours is shown in figure 2 .

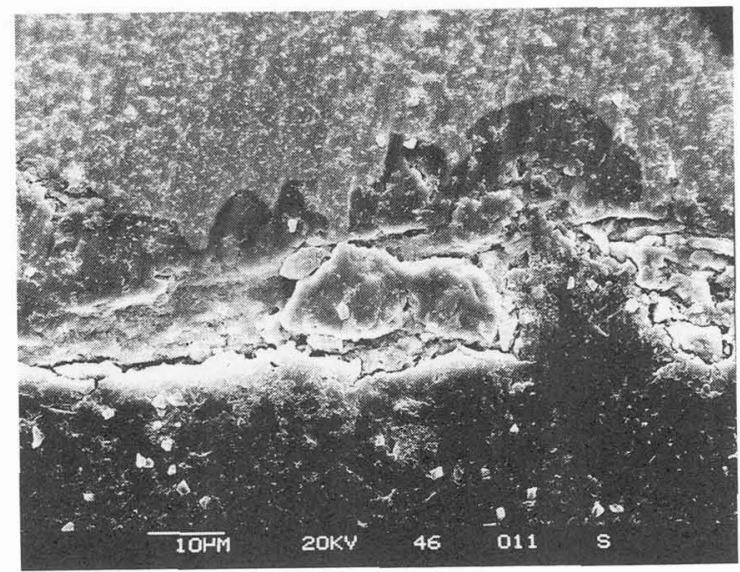

Fig. 2. - Cross-section of Fe-Mn-Al-0.8Si alloy oxidized at $850^{\circ} \mathrm{C}$ for 50 hours; $p_{\mathrm{O}_{2}}=20000 \mathrm{~Pa}$.

Similar observations were realized on the Fe-Mn-Al-0.5Si alloy oxidized under the same conditions except for a greater thickness of the oxide scale. It appears that the outer scale was composed of only $\alpha-\mathrm{Mn}_{2} \mathrm{O}_{3}$. Under this outer scale, a $2 \mu$ m-thick dark $\alpha-\mathrm{Al}_{2} \mathrm{O}_{3}$-containing region was observed. No iron oxide was detected in both sublayers. There were indications of silicon enrichment below the $\alpha-\mathrm{Al}_{2} \mathrm{O}_{3}$ layer. The scale cross-sections were also examined for Fe-Mn-Al alloys (Fig. 3). The oxide layer is non adherent to the substrate and spallation occured during cooling. The whole scale consists of several subscales containing iron and manganese mixed together. The different phases were identified as $\alpha-\mathrm{Mn}_{2} \mathrm{O}_{3}, \mathrm{MnFe}_{2} \mathrm{O}_{4}$ and a small amount of $\mathrm{MnO}$. No $\alpha-\mathrm{Fe}_{2} \mathrm{O}_{3}$ was observed after testing at $850^{\circ} \mathrm{C}$.

\subsection{COATED SPECIMENS.}

3.2.1 Oxidation kinetics. - The weight-gain curves are reported in figure 4 for the coated specimens at $850{ }^{\circ} \mathrm{C}\left(p_{\mathrm{O}_{2}}=20000 \mathrm{~Pa}\right)$. Fe-Mn-Al oxidation kinetics followed the classic parabolic rate law, $k_{\mathrm{p}}=1.6 \times 10^{-11} \mathrm{~g}^{2} \mathrm{~cm}^{-4} \mathrm{~s}^{-1}$. The weight gain registered after 50 hours testing reached $3 \mathrm{mg} \mathrm{cm}{ }^{-2}$. Concerning the silicon-containing alloys (Fe-Mn-Al-0.5Si and Fe-Mn-Al-0:8Si), the weight gains registered after 50 hours oxidation were $4 \mathrm{mg} \mathrm{cm}^{-2}$ and $3 \mathrm{mg} \mathrm{cm}^{-2}$ respectively. 


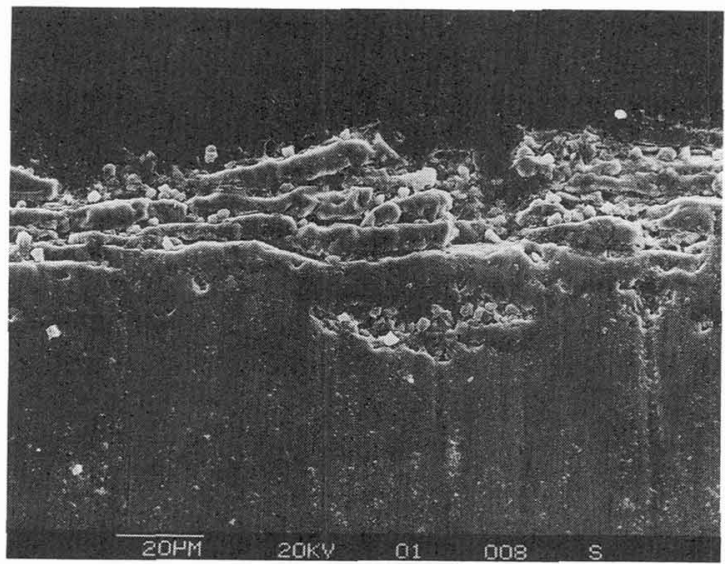

Fig. 3. - Cross section of Fe-Mn-Al alloy oxidized for 50 hours at $850{ }^{\circ} \mathrm{C} ; p_{\mathrm{O}_{2}}=20000 \mathrm{~Pa}$.

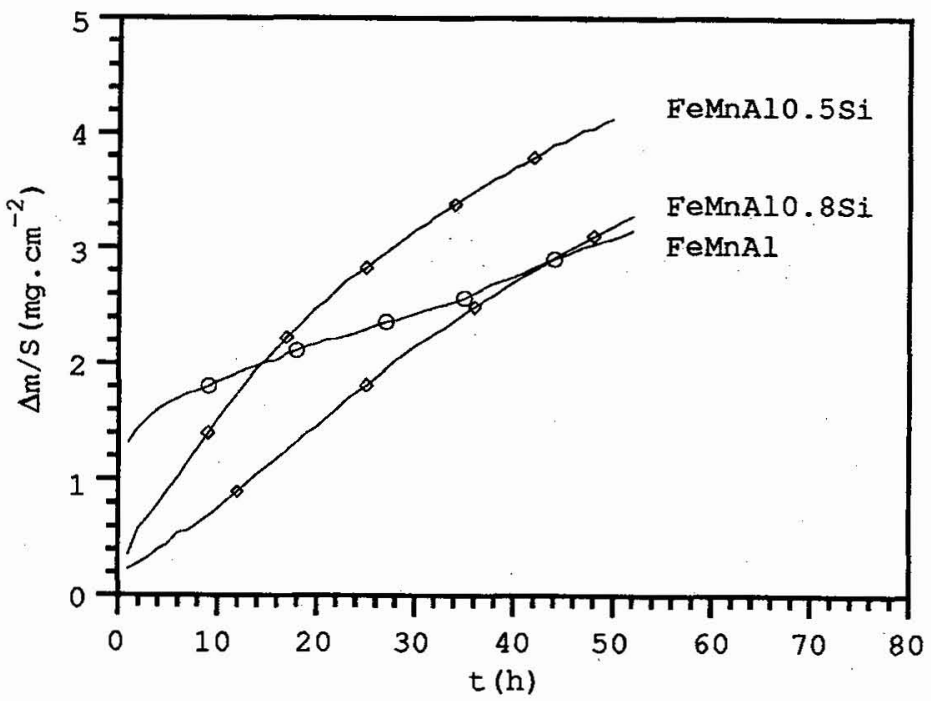

Fig. 4. - Weight-gain curves of the Fe-Mn-Al, Fe-Mn-Al-0.5Si, Fe-Mn-Al-0.8Si coated specimens. $T=850^{\circ} \mathrm{C}, p_{\mathrm{O}_{2}}=20000 \mathrm{~Pa}$.

3.2.2 Oxide scale morphology. - The scale morphology was observed in the cross section of coated Fe-Mn-Al alloy oxidized at $850^{\circ} \mathrm{C}$ for 50 hours. The scale was composed of two $10 \mu \mathrm{m}$ thick subscales containing both iron and manganese in similar proportions. A thin Al-rich zone was found at the scale-alloy interface but cerium was not detected by the analytical techniques used. Oxide scales had generaly the same aspect and composition compared to the uncoated specimens, except a lower thickness was observed. However, after only ten minutes testing a very thin non-adherent $\mathrm{CeO}_{2}$ layer is still present above the iron-manganese oxide scale already formed on the substrate. This $\mathrm{CeO}_{2}$ layer is probably lost during cooling after 
long term experiments.

On the contrary, the cross section of Fe-Mn-Al-0.8Si alloy oxidized at the same temperature exhibited a large difference between coated and uncoated specimens (Fig. 5).

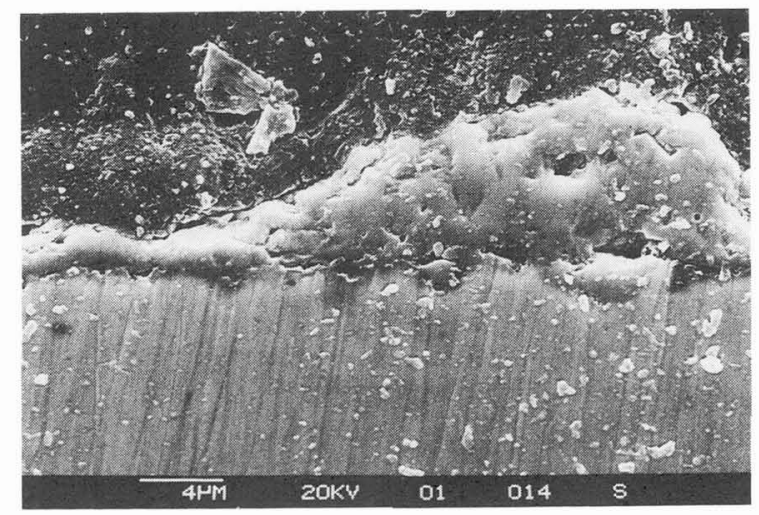

Fig. 5. - Fe-Mn-Al-0.8Si cross-section, oxidized at $850^{\circ} \mathrm{C}$ for 50 hours; $p_{\mathrm{O}_{2}}=20000 \mathrm{~Pa}$.

On coated specimens the scale thickness was larger. The scale comprised two parts. The external subscale was non-adherent and composed of $\alpha-\mathrm{Mn}_{2} \mathrm{O}_{3}$. The inner subscale was composed of $\mathrm{Mn}_{3} \mathrm{O}_{4}$ and $\mathrm{MnO}$, and remained adherent to the substrate. No iron was detected in both subscales and an Al-rich zone associated with silicon was observed at the scale-alloy interface. The observations made after a ten minutes experiment showed a thin, uniform and adherent oxide scale where cerium is mainly incorporated in the outer part. Silicon was observed at the inner interface.

\section{Discussion.}

4.1 EFfect OF SILICON. - The kinetic curves obtained by testing the Si-free alloy exhibit three consecutive parabolic regimes during the 50 hours exposure time. The $k_{\mathrm{p}}$ values calculated for each part of the curve are similar. Moreover, the scale exhibits a stratified morphology. Thus, each part of the curve can be attributed to the growth of one of the subscales. Oxide scale mainly grows on this ternary alloy by outward diffusion of manganese and iron. No evidence of inward oxygen diffusion was observed. Manganese diffuses generally more quickly than iron [15], leading to a higher proportion of manganese in the oxide scale compared with the alloy composition. Also, manganese depletion is observed under the internal interface down to a depth of $10 \mu \mathrm{m}$. This growth mechanism induces vacancy coalescence at the internal interface leading to scale spallation. The ternary alloy, Fe-Mn-Al, was tested to compare its high temperature corrosion resistance with the classical Fe-Gr-Al [6-8, 16]. On $\mathrm{Fe}-\mathrm{Cr}-\mathrm{Al}$ alloys, chromium is serves as an oxygen getter during the initial transient stage of the alloy oxidation [16]. According to thermodynamic stability, chromium affinity for oxygen is intermediate between iron and aluminium. Concerning Fe-Mn-Al alloy, the thermodynamic stability of manganese oxide is close to that for iron oxide. Then, manganese hardly acts as an oxygen getter and the aluminium-rich zone is not observed as a continuous scale. 
When a small amount of silicon is added to the alloy, the $k_{\mathrm{p}}$ values are about one order of magnitude lower than those obtained with the silicon-free alloy. Moreover, the mass gains are lowered with an increasing amount of silicon. We have also observed that the composition of the scale is basically changed. Only manganese is present in the outer part of the scale. At the scale substrate interface, the silicon is associated with aluminium and no separate silica layer is observed. Oxide scale still grows by outward cation diffusion, but this mechanism is strongly influenced by the presence of silicon. It increases the oxidation rate of aluminium during the transient stage. Silicon also affects the cation diffusivity by incorporation into alumina. Thus, a thin protective alumina layer is formed and iron diffusion is stopped $[9,10,17]$. Other experiments have been performed on $\mathrm{Fe}-\mathrm{Mn}-\mathrm{Si}$ alloys [17] and it has been shown that silicon alone never lead to the formation of a diffusion barrier against iron. This proves that the effect of silicon on the oxidation process is due to a synergy between aluminium and silicon.

4.2 EFFECT OF CERIUM. - The silicon-free alloy coated by cerium hydroxide always exhibits a lower mass gain compared with uncoated specimens. Oxidation kinetics follow a linear law after the transient stage. Iron and manganese are present together in the scale. These observations can be attributed to cerium oxide scale formation at the external interface. This scale limits the oxygen diffusion down to the reaction front. Under the thin cerium oxide scale the iron-manganese oxide layer is still growing by outward cation diffusion. In this case, the results cannot be attributed to a grain boundary segregation of $\mathrm{CeO}_{2}$ particles acting on the diffusion paths.

Silicon-containing alloys after dipping in the cerium containing solution always give higher mass gains compared with uncoated specimens. Only $\alpha-\mathrm{Mn}_{2} \mathrm{O}_{3}$ and $\alpha-\mathrm{Al}_{2} \mathrm{O}_{3}$ were observed on uncoated specimens, but $\mathrm{Mn}_{3} \mathrm{O}_{4}$ and $\mathrm{MnO}$ are also observed on coated samples. Finally, cerium was included in the scale formed during the first ten minutes oxidation. It seems that cerium is only incorporated in the scale when alumina is grown during a transient stage in the presence of $\mathrm{Si}$. This is probably due to a faster formation of the alumina scale, or because the diffusion properties of alumina are modified by silicon.

One possible explanation of these results could be the formation of a mixed oxide $(\mathrm{Si}, \mathrm{Ce})_{2} \mathrm{O}_{7}$ leading to the annihilation of the effects of silicon. However, silicon is still playing its role in the diffusion process. No iron is present in the oxide scale, and silicon and cerium have never been observed together at the same place.

More probable is the induction of internal oxidation of manganese under a ceriumcontaining external scale leading to the observed $\mathrm{Mn}_{3} \mathrm{O}_{4}$ and $\mathrm{MnO}$ phases. In addition, we can consider that the external diffusion of manganese is still possible, giving the observed $\alpha-\mathrm{Mn}_{2} \mathrm{O}_{3}$ scale.

\section{Conclusions.}

On Fe-Mn-Al alloy, when the temperature is higher than $750{ }^{\circ} \mathrm{C}$, non-protective iron and manganese oxides form during the transient stage. The process is too fast to establish a diffusion barrier with a continuous alumina scale formed according to the low partial pressure maintained at the internal interface.

It seems that silicon has two effects. It increases the aluminium oxidation rate during the transient stage and secondly modifies the diffusion properties of $\alpha-\mathrm{Al}_{2} \mathrm{O}_{3}$, eliminating iron diffusion.

According to our results, cerium deposition on Fe-Mn-Al alloy leads to improved behaviour attributed to the presence of an external cerium oxide scale limiting the oxidation process. It 
seems that cerium is not incorporated in such scales. On the other hand, silicon-containing alloys promote the incorporation of cerium in the scale formed during the transient stage. Then, oxidation is increased due to an additional internal oxidation process.

\section{References}

[1] HAM J.L., CaIRnS R.E., Prod. Eng. N.Y. 29 (1958) 50.

[2] PereZ M., LARPin J.P., Oxid. Met. 24 (1985) 29.

[3] SMEltzer W.W., Elrefaie F.A., Proc. 9th, I.G.M.C., 2 (1984) p. 24.

[4] MOON D.P., BENNETT M.J., Mater. Sci. Forum. 43 (1989) 269.

[5] SCHMATZ D.J., Trans. AIME 215 (1959) 112.

[6] SAUER J.P., RAPP R.A., HiRTH J.P., Oxid. Met. 18 (1982) 285.

[7] WANG R., STRasZheim M.J., Rapp R.A., Oxid. Met. 21 (1984) 71.

[8] ERHART H., WANG R., RAPP R.A., Oxid. Met. 21 (1984) 81.

[9] Bernabai U., Capuano G.A., Dang A., Felli F., Oxid. Met. 33 (1990) 309.

[10] Felli F., Bernabai U., CaVallini M., Metall. Sci. Techn. 3 (1985) 87.

[11] OH J.M., J. Electrochem. Soc. 134 (1987) 3209.

[12] STRINGER J., Mater. Sci. Eng. A 120 (1989) 129.

[13] MaYer P., SMeltzer W.W., J. Electrochem. Soc. 119 (1972) 626.

[14] BUSCAIL H., Thesis, University of Bourgogne (1987).

[15] ERHART H., WANG R., RAPp R.A., Oxid. Met. 21 (1984) 81.

[16] WaGner C., Corros. Sci. 5 (1965) 751.

[17] ATKInSON A., GARdner J.W., Corros. Sci. 21 (1981) 49. 